原 著

\title{
仰臥位と腹臥位で眼振方向が変化した一例
}

永井 賀子 ${ }^{1)}$ - 小川 恭生 ${ }^{2)} \cdot$ 大塚 康司 $^{3)}$ ・稲垣 太郎 ${ }^{4}$

\section{A case of persistent direction-changing positional nystagmus}

\author{
Noriko Nagai ${ }^{1)}$, Yasuo Ogawa ${ }^{2)}$, Koji Otsuka ${ }^{3)}$, Taro Inagaki ${ }^{4)}$ \\ ${ }^{1)}$ Department of Otolaryngology, Kohsei Chuo General Hospital \\ ${ }^{2)}$ Department of Otolaryngology, Tokyo Medical University Hachioji Medical Center \\ ${ }^{3}$ Department of Otolaryngology, Tokyo Medical University Ibaraki Medical Center \\ ${ }^{4)}$ Department of Otolaryngology, Tokyo Medical University
}

\begin{abstract}
Direction-changing positional nystagmus is commonly observed in patients with benign paroxysmal positional vertigo of the horizontal semicircular canal type. There are two types, namely, attenuating geotropic nystagmus and persistent apogeotropic nystagmus. The former is thought to be caused by canalolithiasis with the debris located in the horizontal semicircular canal and the latter is caused by cupulolithiasis with the heavy debris attached to the cupula of horizontal semicircular canal. In addition, there are rare cases of persistent direction-changing positional nystagmus, in which the nystagmus does not decay and is of long duration. The pathogenesis of this type of nystagmus is thought to involve a light cupula, because it is explained by the deflection of the cupula in the antigravity direction, but the precise mechanism is still unknown. We encountered a case of vestibular Meniere's disease with recurrent attacks of vertigo, in which the direction of nystagmus changed between the supine and prone positions, and stopped at about 90 degrees below the left and right ears.
\end{abstract}

Key words: direction-changing positional nystagmus, BPPV, Meniere’s disease

\section{はじめに}

頭位検査での方向交代性眼振は外側半規管型良性 発作性頭位めまい症（外側半規管型 BPPV）でよく 観察される眼振で，持続時間が短く，減衰する方向 交代性下向性眼振を示す症例と, 持続時間の長く持 続する方向交代性上向性を示す症例がある。前者は 半規管内へ迷入した結石 (半規管結石症)，後者は

\footnotetext{
1) 厚生中央病院耳鼻咽喉科

2) 東京医科大学八王子医療センター耳鼻咽喉科・頭頚 部外科

3) 東京医科大学茨城医療センター耳鼻咽喉科

4) 東京医科大学耳鼻咽喉科・頭頚部外科学分野
}

クプラに付着した結石（クプラ結石症）によるもの と考えられている。それら以外に，稀に眼振が減衰 せず持続時間が長い持続性方向交代性下向性眼振を 示す症例も存在することが知られている。この眼振 の病態は反重力方向へのクプラの偏倚で説明される ので Light cupula と考えられているが, 眼振の発現 機序はいまだ不明である。

今回, 我々は, 前庭型メニエール病と診断し, 経 過観察中, 仰臥位と腹臥位で眼振方向が変化し, 眼 振停止点が左右耳下約 90 度にあり, めまい発作を反 復する 1 例を経験し, 眼振の機序について考察し た。 


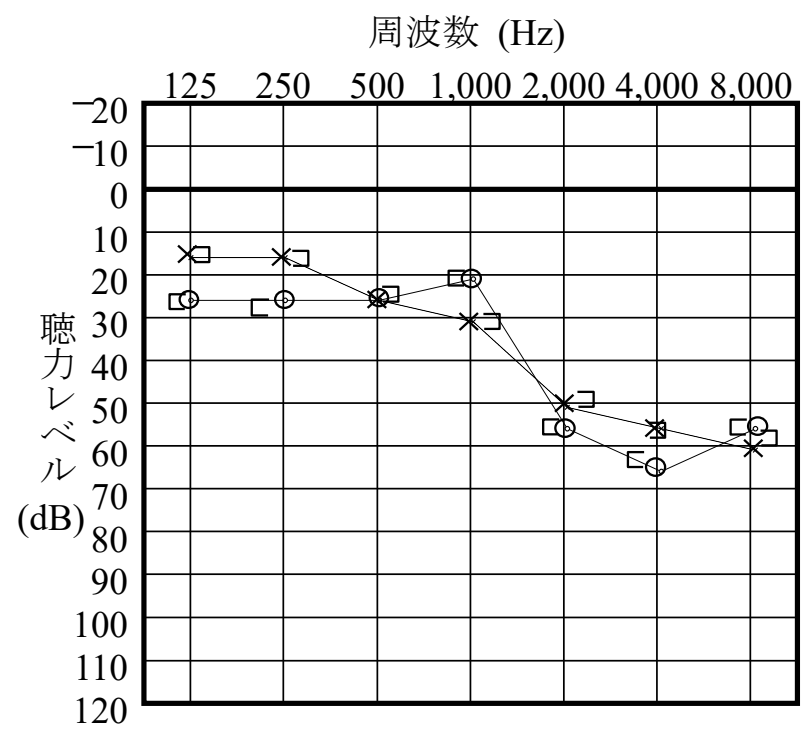

図 1 初診時 純音聴力検査 両側ともに高音域に難聴がみられたが左右 差は無かった。

\section{症例}

69歳 女性

現病歴：

$200 \mathrm{X}$ 年, 頭位変換時のめまいが複数回あり他院 に通院していた。200X+3 年, 臥位で安静時にも めまい感が出現し転居に伴い受診した。

既往歴：特になし

家族歴：特になし

初診時現症：中枢障害を疑わせる所見はなく，自 覚症状もなかった。鼓膜所見は正常で，そのほか耳 鼻咽頭喉頭に異常所見はなかった。左耳閉感を訴え ており, 純音聴力検查は両側ともに高音域に難聴が みられたが左右差は無かった（図 1 )。CCD カメラ 下頭位眼振検査では, 坐位正面で右向き水平性眼 振，臥位正面，右下頭位，左下頭位で右向き水平性 眼振があり，左下頭位 90 度，右下頭位 100 度で眼振 は消退した。腹臥位で左向き水平性眼振を呈し, 腹 臥位右下頭位，腹臥位左下頭位でも左向き水平性眼 振があった。左下頭位 90 度, 右下頭位 100 度以外の 頭位では眼振は減衰せず持続性であった（図 2 )。 閉眼足踏み検查（50歩）では左に90度偏倚した（図 2 )。図 3 に眼振の模式図, 図 4 に動画を 2 次元解 析した図を示す。赤外線 CCD カメラの眼球運動の 画像をiPhone を用いて動画記録し, NIH Image 用いた簡易眼球運動画像解析法にて 2 次元解析をお
こなった ${ }^{1)}$ 。図 4 は左から, 仰卧位正面から右下頭 位, 左下から左下頭位 90 度への変化, 左下頭位 100 度，右下頭位 100 度，腹臥位の眼振を示す。仰臥位 正面から右下頭位では右向き眼振があり, 左下頭位 では右向き眼振がみられるが左下頭位 90 度で眼振の 消失, 左下頭位 100 度で左向き眼振への変化が確認 できる。右下頭位 100 度で左向き眼振, 腹臥位で左 向き眼振が示されている。

経過：初診時のめまいは約 1 か月で軽減したが, その後も同様のめまい発作を反復した。頭位眼振検 查では, 初診時と同様の仰臥位, 腹臥位で眼振が変 化した所見が主であったが，それ以外に異常眼球運 動が無い日もあれば，方向交代下向性眼振，左向き 水平性眼振や, 右向き水平性眼振がみられた日もあ った。経過中, 閉眼足踏み検査は左180度に偏倚し た。内耳機能検査は, 温度眼振刺激検查, 前庭誘発 頸筋電位 (Cervical Vestibular Evoked Myogenic Potentials; cVEMP), 前庭誘発外眼筋電位 (Ocular Vestibular-Evoked Myogenic Potentials ; oVEMP) (図 5 ), video Head Impulse Test (vHIT) を行っ た。温度刺激眼振検査はエアーカロリック法で行 い, $15^{\circ} \mathrm{C} 6 \mathrm{~L} /$ 分, 刺激時間は 60 秒で行った。温度 刺激眼振検査では最大緩徐相速度は右 $21.5^{\circ}$, 左 $20^{\circ}, \mathrm{CP} \%$ は. $6 \%$ であり半規管麻痺はなかった。 cVEMP は左右の振幅の比が他側の $1 / 2$ 以下であ る場合を反応低下とした。cVEMPの結果は正常で あった。OVEMP は前額部正中の骨導刺激で行い, 振幅から Asymmetry ratio $(\mathrm{AR})=\mid$ (larger amplitude -smaller amplitude)/(larger amplitude + smaller amplitude) $\mid \times 100$ を計算し, 正常上限は Nagai ら ${ }^{2)}$ の データより設定し49.7とした。OVEMPの ARは 12.6であり正常であった。vHITの vestibulo ocular reflex (VOR) gain は右0.96, 左0.92, で両側とも に catch up saccade はなかった。これらの内耳機能 検査結果で異常はみられなかった。また, 経過中に 聴力の変動はなかった。さらに, 頭部 MRI 検査で は特に有意な異常所見はなかった。以上の結果か ら，2017年に改訂された日本めまい平衡医学会のメ ニエール病非定型例診断基準 ${ }^{3)}$ から， $\mathrm{A}$ 症状， $\mathrm{B}$ 検 査所見ともに項目を満たしたためメニエール病非定 型例 (前庭型) と診断した。現在，めまい発作は 時々出現しているものの保存的に経過を観察してい 

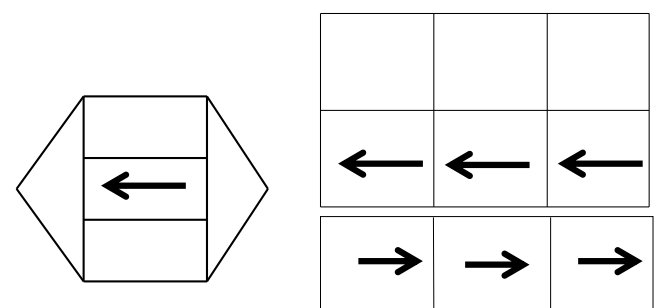

前屈

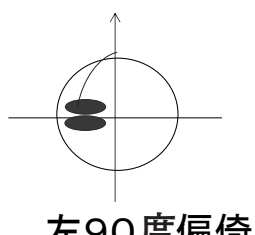

図2 初診時所見

注視眼振検査, 頭位眼振検査を左図に示す。注視眼振検査では正面で 右向き眼振，頭位眼振検査では，臥位正面，右下，左下で右向き眼振 があり，さらに左下，右下に頭位を傾けると眼振は消退し左向き眼振 に変化した。腹臥位では左水平性眼振を呈し, 腹臥位右下, 左下頭位 でも左水平性眼振がみられた。眼振は減衰せず持続性であった。閉眼 足踏み検査（右図）では左に90度偏倚した。

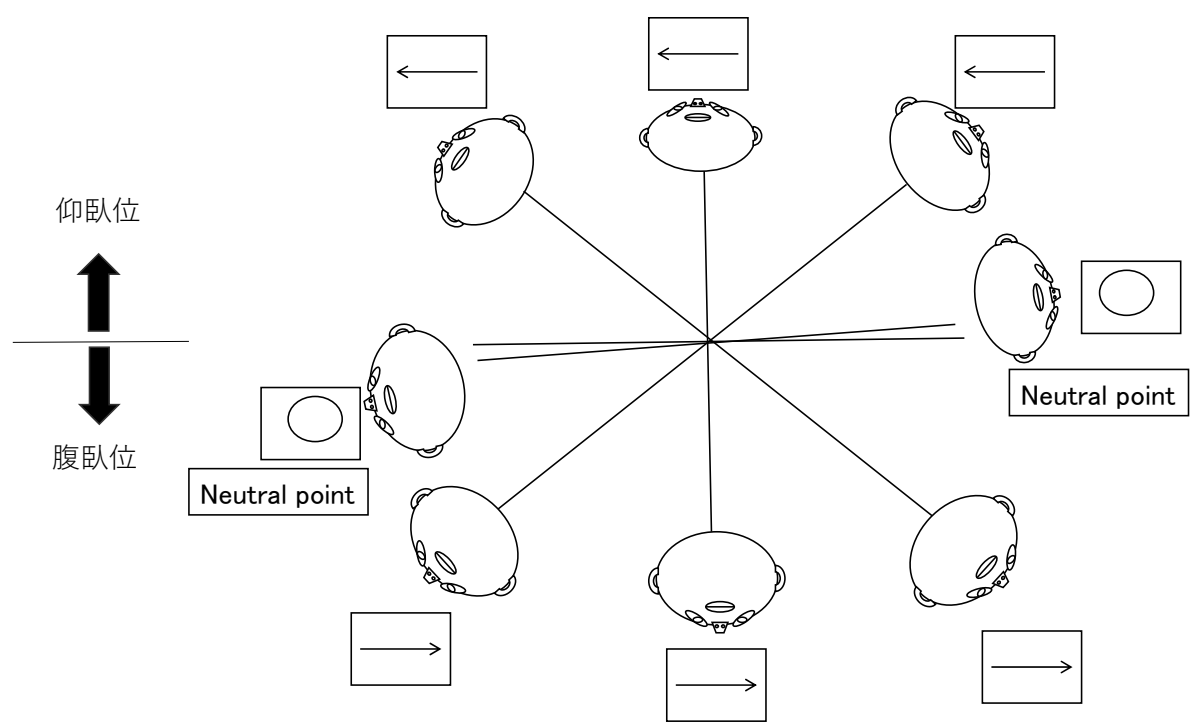

図3＼cjkstart初診時の眼振所見の模式図

初診時の眼振所見を模式図で示した。仰臥位で右向き眼振, 腹臥位で左向き 眼振, neutral pointは約90度を呈した。

る。

\section{考察}

外側半規管型良性発作性頭位めまい症では，方向 交代上向性眼振と方向交代下向性眼振がみられる。 前者は眼振の減衰が無く持続する例のみだが, 後者 は眼振の減衰がある例とない例の 2 つに大別され る。方向交代性上向性眼振は, クプラに付着する耳 石, Heavy cupula と考えられており，また，減衰 のある方向交代性下向性眼振は半規管に迷入する耳 石によって説明可能である。一方，持続性方向交代 性下向性眼振は, 一側の外側半規管のクプラに軽い
浮遊物が付くなどの軽いクプラ理論によって説明が 可能とされている(4) 6)。多くの場合, 外側半規管の クプラは先端が外側を向いているため, クプラが重 力方向と一致する角度だけ患側方向に傾けると眼振 の停止点（neutral point）がある。

持続性上向性頭位眼振から持続性下向性頭位眼振 に移行した一例の経過中に，今回の症例と同様の所 見がみられている報告がある7)。4日連続して頭位 眼振検查を行っており, 発症当日はやや左下に neutral point がある持続性上向性眼振，2 日目に右へ の方向固定性眼振, 腹臥位で反転する左向き水平性 
Equilibrium Res Vol. 80(4)

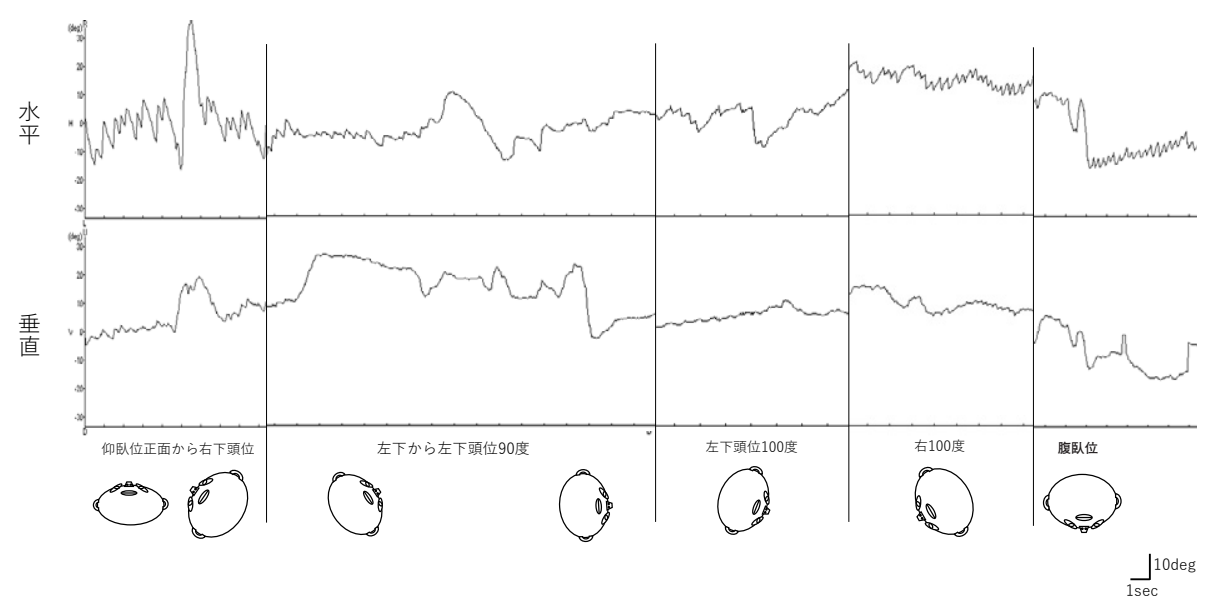

図4 動画を 2 次元解析した図

左から, 仰臥位正面から右下頭位, 左下から左下頭位 90 度, 左下頭位 100 度, 右下頭位 100 度, 腹臥位の眼振を示す。仰臥位正面から右下頭位では右向き 眼振, 左下から左下頭位 90 度で右向き眼振が消失, 左下頭位 100 度で左向き 眼振に変化しているのがわかる。右下頭位 100 度で左向き眼振, 腹臥位で左 向き眼振が示されている。
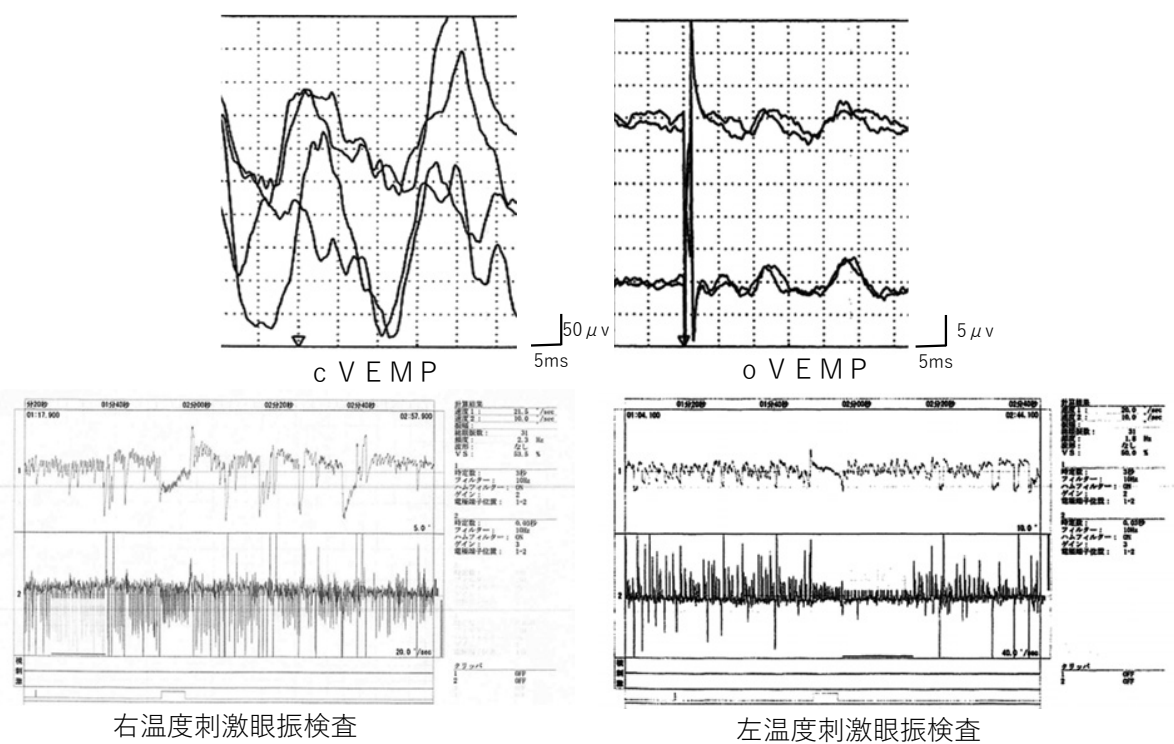

図5 内耳機能検査

温度刺激眼振検查 最大緩徐相速度 右 $21.5^{\circ} /$ 秒, 左 $20^{\circ} /$ 秒 $\mathrm{CP} \%$ は 3. $6 \%$ であり半規管麻痺はなかった。

cVEMPは両側反応あり正常であった。oVEMPの Asynmmetry ratio は 12.6 であり正常であった。

眼振，3日目にやや左下に neutral point がある持 続性下向性眼振, 4 日目にやや右下に neutral point がある持続性下向性眼振がある症例で, 発症 2 日目 の眼振が本症例と同様の所見であった。この症例で は眼振が固定せず移行しており, 方向固定性眼振で
はなく発症 2 日目の水平性眼振も頭位眼振と考えら れている。我々の経験した症例は，外来で眼振検査 を連日行っていないため眼振の変化の推移の観察が 不十分ではあるが，別日に行った眼振検査でも初診 時と同様に左右耳下約90度に neutral point があり 
仰臥位と腹臥位で眼振が反転する所見が複数回あ り，本症例で診られた眼振のすべてが頭位眼振とは 考えにくい。Heavy cupula 症例や Light cupula 症 例の仰卧位での neutral pointの角度は症例によっ て異なることが報告されている8 Light cupula ではクプラの解剖学的違いから neutral pointの位置が異なることは説明可能であるが，本 症例での左右耳下約90度に neutral point が存在す る理由はクプラの解剖学的違いからは説明ができな い。

初診時に仰臥位で診られた右向き水平性眼振は, 左の内耳機能低下による麻疩性眼振と考えた。前屈 位での左向き眼振は水平性眼振であるため外側半規 管由来であり，また，刺激性眼振であるため Ewald の第一法則から向膨大部の内リンパ流動の存在を考 えた。患側外側半規管膨大部に向かう内リンパ流動 が起こる機序としては, 患側クプラの膨大部方向へ の偏倚を考え, 膨大部の組成の比重が低いことやク プラや外側半規管の水腫の存在によって圧力でクプ ラが偏倚した可能性が考えられる。腹臥位でのクプ ラ偏倚による興奮性が，もともとべースにある左の 内耳機能低下を上回って, 左向きの眼振が生じる可 能性もある。本症例では耳閉感を訴えてはいたが難 聴がなかったため, 球形囊や螖牛, 卵形囊の周囲と いうよりはクプラや半規管の水腫の存在を疑った。 通常の方向交代性眼振は重力に依存するが, 今回の 症例は腹臥位で眼振が変化するため通常の重力依存 とは異なる。クプラ周囲組織によりクプラが圧迫, 圧排されて向膨大部方向に偏位もしくは卵形囊が刺 激状態になったと考えられるが原因は明確に言及で きない。

メニエール病の側頭骨病理では内リンパ水腫の程 度は球形囊 $\rightarrow$ 蝸牛 $\rightarrow$ 卵形囊 $\rightarrow$ 半規管の順で顕著と報 告されており，蝸牛はライスネル膜の前庭階への変 位が特徵的で軽症でもわかりやすいが，三半規管は 厚い膜迷路からなっているため重症にならないと内 リンパ水腫の検出が難しいと報告されている9”。前 庭型メニエール病の側頭骨病理は涉編しえた範囲で は報告がなく, クプラ周囲のみや半規管のみの水腫 は存在するかどうかはわからない。また，内耳障害 がより高度な症例において腹臥位眼振検査で眼振方 向が変化しやすいと報告されている ${ }^{10)}$ 。本症例で
は，腹臥位で眼振方向が変化したことから内耳障害 が高度である可能性があるが, 内耳機能検査では異 常を認めず，蝸牛症状がないため, クプラや半規管 単独の内リンパ水腫の可能性を否定はできない。近 年, メニエール病の MRIによる画像診断の有用性 が報告され ${ }^{111}$, 前庭型メニエール病では蝸牛に比べ 前庭に有意に多く内リンパ水腫を認めたと報告され ている ${ }^{12)}$ 。本症例の施設ではメニエール病を診断す るための 3 テスラ MRI 機器が入っておらず, 画像 で内リンパ水腫の同定ができていないが，今後積極 的に検討するべき検査である。

本症例の眼振の機序を考察し，メニエール病の中 には球形囊や蝸牛の水腫以外に, クプラや外側半規 管単独の内リンパ水腫が存在する可能性があり, 今 後は前屈位もしくは腹臥位眼振の症例を多く観察す ることで何か新しい知見が報告できればと考える。

まとめ

・仰臥位と腹臥位で眼振方向が変化し, ニュート ラルポイントが左右耳下約 90 度にあり, めまい発作 を反復する持続性方向交代性眼振の 1 例を経験し, 眼振の機序について考察した。

・前屈位または腹臥位眼振を多く観察することで メニエール病や他のめまい疾患での病態について考 察できる可能性を考えた。

\section{文献}

1) 池田卓生, 橋本 誠, 堀地 修, 他: NIH Image を用いた簡易眼球運動画像解析法 三次元 解析と回転軸解析について. Equilibrium Res 61: 90-96, 2002

2) Nagai N, Ogawa Y, Hagiwara A, et al.: Ocular vestibular evoked myogenic potentials induced by bone-conducted vibration in patients with unilateral inner ear disease. Acta Otolaryngol 134: 151-158, 2014

3 ）めまいの診断基準化のための資料 診断基準 2017年 改訂 Equilibrium Res 76: 233-241, 2017

4 ) Hiruma K, Numata T: Positional nystagmus showing neutral points. ORL J Otorhinolaryngol Relat Spec 66: 46-50, 2004

5 ）一條宏明：持続型方向交代性下向性頭位眼振の 病態.耳鼻臨床 $97 ： 781-787,2004$ 
6 ) Bergenius J, TomanovicT: Persistent geotropic nystagmus-a different kind of cupular pathology and its localizing signs. Acta Otolaryngol 126: 698-704, 2006

7 ）重野浩一郎：末梢性方向交代性頭位眼振と外側 半規管型良性発作性頭位めまい症. Equilibrium Res 74: 228-237, 2015

8 ) Ichijo H: Neutral position of persistent direction -changing positional nystagmus. Eur Arch Otorhinolaryngol 273: 311-316, 2015

9 ) Okuno T, Sando I: Localization, frequency, and severity of endolymphatic hydrops and the pathology of the labyrinthine membrane in Meniére's disease. Ann Otol Rhinol Laryngol
96: 438-445, 1987

10）稲垣太郎, 小川恭生, 大塚康司, 他 : 末梢性め まい症例における腹臥位頭位眼振検查の検討. Equilibrium Res 71: 78-86, 2012

11）曾根三千彦：耳科領域に扮ける画像診断法の最 前線 内リンパ水腫一画像評価とその意義. Equilibrium Res 74: 303-307, 2015

12) Kato M, Sugiura M, Shimono $M$, et al.: Endolymphatic hydrops revealed by magnetic resonance imaging in patients with atypical Meniere's diseases. Acta Otolaryngol 133: 123129, 2013

利益相反に該当する事項はない。 